\title{
The ECHELON Trail: An Illegal Vision.
}

\author{
Steve Wright1
}

\begin{abstract}
This article tells the story behind the uncovering of the US operated global telecommunications interceptions system now known as ECHELON. It begins with the use of fieldwork techniques in the early 1970's exploring the configuration of Britain's Post Office Towers - these were ostensibly the microwave links through which Britain's long distance telephone calls were made. This modelling process revealed a system within the system of microwave towers linked to the American Base of Menwith Hill in the North York Moors. All the key researchers were then promptly arrested, a raid by Special Branch on the author's university at Lancaster ensued and later a show trail for the other main researchers, most notably Duncan Campbell. Eventually in 1988, Duncan wrote up the ECHELON story, which for its time was an incredible piece of detective work using materials lifted from waste bins by the women activists campaigning around the Menwith Hill Base. Little notice was taken until 1997 when an obscure book by Nicky Hager, Secret Power explained the role and function of ECHELON in more depth. The author represented these findings in a policy report to the European Parliament on the technology of political control that led to a process of political debate and disagreement of the ethics of such a system which continues even today.
\end{abstract}

\section{Introduction}

Studies of surveillance are challenging, and often demand a sustained research commitment. It is no coincidence that many of the key British researchers active in this field in the early 1970's remain so today. I am currently still working on issues of what are essentially tools of social and political control - both professionally as an Associate Reader at Leeds Metropolitan University in the Praxis Centre, ethically as a lecturer in the School of Applied Global Ethics and politically as chair of the Board of Trustees of Privacy International.

This article describes how I became engrossed in studying 'technologies of political control', and tracked the members of the security industrial complex, responsible for proliferating it to some of the world's most unsavoury regimes. More specifically, it relates how a lowly postgraduate researcher stumbled across the entrails of a global telecommunications interception system; precipitated the first Special Branch police raid on a British University; provoked the first ever parliamentary debate on the British secret police; and accidentally detonated a worldwide political and ethical debate on the

1 Praxis Centre for the Study of Information \&Technology for Peace, Conflict Resolution \& Human Rights, Leeds Metropolitan University, School of Information Management, mailto:s.t.wright@leedsmet.ac.uk 
existence of a futuristic global electronic spying network, now known as 'ECHELON'. In relating my personal experience of researching the ECHELON trail, I hope to illustrate how many of the challenges facing surveillance scholars during critical periods of their work can be faced and eventually overcome without the researcher becoming part of the food chain of the process they are watching.

ECHELON is a (now out-of-date) code name given to the US National Security Agency's worldwide facility for the mass interception of electronic telecommunications including, phone, fax and email using key words and context. It works on the basis that other telecommunication links can be used to siphon off messages travelling by satellite, microwave relay link or fibre optic cable, if they intercept such streams at a key node, and can work at a prodigious rate of more that 2 million intercepts per hour. Essentially, the system can work because for some of its journey, telecommunications traffic is travelling as an electronic stream that can be intercepted if the appropriate infrastructure is in place. However, the current wisdom is that ECHELON does not exist in the way it was originally construed but is a now thought to be a collection of subsets of interception capabilities using a range of code names of which we remain ignorant. Nevertheless, for the sake of simplicity, it makes sense to continue to use the generic label 'ECHELON' whilst recognizing that new surveillance algorithms have evolved since the early researchers built their crude paradigms.

My interest in surveillance studies began over three decades ago when no such field existed. I was a student at Manchester University on an unusual course, entitled 'Liberal Studies in Science'. The course attempted to bridge the communication gap between science and the humanities, and create 'literate scientists' (in the wake of C.P Snow's famous critique of the 'two cultures'). The training given by the course certainly paid off in the years which followed, since it enabled its students to look at specific technical problems with perspectives from many different disciplines.

I became fascinated by the process of technology assessment: the attempt to examine unforeseen impacts of technological innovation. For example, the course examined nuclear arms races, and the parallels with arms races emerging in counter-insurgency conflicts, which were then in the news, fired my imagination. The course's coverage of the Vietnam War highlighted a new generation of military systems which had potential domestic uses such as helicopter-mounted flight stabilized CCTV night vision cameras, already beginning to find a market in policing the U.S. home front.

At the same time on the UK home front, the British Society for Social Responsibility in Science (BSSRS) was just beginning to examine the deployment of new weapons and technologies in the burgeoning 'troubles' in Northern Ireland: a province that was about to become the most surveilled zone in Europe. BSSRS conceptualized this new equipment as a 'technology of political control'. According to BSSRS, this technology encompassed new crowd control technologies designed to appear safe (rather than be safe), new torture technologies designed to induce psychological breakdown; and new surveillance and telecommunication systems that provided a powerful nervous system for 'the strong state'. 


\section{A Fledgling Researcher}

Managing the transition from being someone who is broadly interested in social and political matters to a so-called 'surveillance scholar' is not a simple matter. It's hardly a direct process, and the zigzags require a talent for organising adequate time, resources and relationship issues that can potentially blight the career of any fledgling researcher.

More important than any of these practical difficulties is the matter of personal determination which, in any new field, hovers precariously close to obsession if the contribution is to sustain. In the case of the field research on ECHELON, which, in the early days, was largely to do with the orientation of aerials, this obsession risks being classified as Asperger's syndrome of which collecting images of antennae can, in some cases, be symptomatic! The syndrome is worth looking up to see if you have these symptoms - but essentially the complaint involves an inward obsession, some impairments in social interaction and repetitive behaviour patterns - named after Hans Asperger (1906-1980), an Austrian paediatrician.

Nevertheless, whatever leads to the strong motivation to study a particular strand of surveillance must be more powerful than the inevitable setbacks that will emerge along the way, including no money, no recognition, no job and no progress. This has probably changed somewhat today since surveillance studies have become more mainstream. Yet it is still reasonable to suggest that for the new or less established scholar, the more controversial the study, the more likelihood there is of roadblocks and the higher the need for networks and support. However, some of the most cutting-edge conceptualization is always done alone. Indian philosophers have a term for it -Tapasia - or straightening by fire.

I can trace my own motivation back to the summer of 1973, when I experienced in India what in retrospect I can only describe as epiphany (see below). It was an intense time. I was travelling East through Afghanistan during the summer holidays and there was a coup d'etat on my $21^{\text {st }}$ birthday. I was out on the streets of Kabul and managed to snatch a picture of the new President Muhammad Daoud. If I could have got across the Khyber Pass and delivered the picture to Reuters, it would have paid for the entire trip. Alas my film was taken at gun point a few minutes later by one of his armed guards, which was an early lesson in the power and politics of stolen images in a time of revolution. My later work was to focus on obtaining good evidence of the deployment of certain technologies, an activity that depends, paradoxically, on the use of surveillance technology to contradict more official claims of what was going on.

Today I see all politics as flows of information, management, manipulation and paradigm change: in my view those who control information control the physical world too. Back then it emerged into my thinking in an almost mystical way, in one of the most sacred Hindu towns of India, Benares. I was watching a never-ending stream of bodies being brought on to the burning grounds for incineration. It was a smoking vision of Hell with semi-naked figures turning over the corpses to burn them more effectively. What was once a human face was cleanly lifted off the skull - the mask of life was now rendered into fried meat. We all end up as ashes but even here, the ashes were being eaten by pyre dogs feeding on bits of backbone with loose remnants of human flesh hanging off. 
I had a semi-visionary experience of witnessing a scene from Bosch. 'The Garden of Earthly Delights' had turned sour and I was left wondering whether any of us could ever make a difference to such a revolting production line. It became a metaphor. My meditation turned to war and the accelerating, endless, disgusting waste of it all. I felt I wanted to make a stand against a technological determinism that turned us into helpless watchers or worse, collaborators. With just $£ 20$ in my pocket, I made the long journey home and a determination never to give up.

Within two years I had focussed my research on new social control and death technologies. New weapons for internal control were emerging for sub-state conflict control during counter revolutionary operations whilst to me unbelievably hideous fragmentation weapons containing thousands of razorblade-like flechettes were being evolved for more conventional warfare - with civilians being the inevitable consumers.

I was convinced that much of the crowd control and 'torture lite' technology I had begun to research in Northern Ireland would be adapted and adopted eventually by all states wishing to technically fix their social and political problems. (This has indeed been the case and much of the technology used in Northern Ireland now forms part of the burgeoning crowd control and internal security sales market. The sensory deprivation based 'torture lite' techniques developed in Northern Ireland have most recently found their way into the US Guantanamo Bay internment camps in Cuba and to Abu Ghraib Prison in Iraq.

None of this early research exploration could be followed very adequately at the undergraduate level of degree I was then pursuing in the UK. Determined to find a new niche, I decided to follow a course of postgraduate study. Unfortunately, my degree level was insufficient to justify finance. My thesis was so difficult to assess by conventional criteria, after debate amongst the examiners, it was upgraded from a poor level pass, to what was essentially a distinction grade. This was largely because of the sheer vision of political control technologies it had sought to encompass. The British degree system uses face to face meetings with external examiners in cases where there is any doubt. I had such an interview in 1975 where alas, I had a technical argument with my external examiner, Brian Flowers, who was later to become Chancellor of Manchester University. So that was that. I was out in the cold and had to find less academic work. However, Flowers did suggest that even though I was a hot-headed young man I should find a way of pursuing my research. Just weeks later, I was employed by the University's Gardening Centre and as luck would have it ended up sweeping the roads just outside my old department in the Maths Tower. One day, the Head of the Department, Professor Michael Gibbons walked by, and seeing my lowly station remarked, "that'll teach you to argue with Brian Flowers.! “

But serendipity can play a fateful role in any researcher's life: they key lesson is to accept the blows but never give up. Fortunately, I had found a place where I could do the research work I wanted and was accepted at Lancaster University's Programme of Peace and Conflict Research. In the meantime, I'd noticed an article in the Guardian that said that Brian Flowers was being considered to be the next scientific advisor to the government. 
I wrote to Brian Flowers saying I had followed his advice, had found a suitable course to continue my research and perhaps he could suggest where I might find the resources to follow it through? Lesser men in authority would have dismissed such a cheeky request from an eccentric student determined to follow an unusual research topic: 'Social Control and Death Technologies.' To his credit, and my everlasting gratitude, the now Lord Sir Brian Flowers found a way of assisting the funding of my studies in that crucial first year, through a grant from the Society for Education in the Applications of Science. Without that essential first funding, I would have lost so much impetus. Timing is often everything but I've never lost that early lesson in the vital skill of fund raising, that every critical researcher must learn.

\section{The Programme of Peace and Conflict Research}

By October 1976 I was ready to travel to Lancaster University. It had been an eventful year. I had married in the 1975, a son had been born the following spring, but I had secured a place, finance, a house and a creative supervisor, Dr. Paul Smoker. Yet the single-minded need to relentlessly pursue the research took its toll on the time I devoted to my family. From my perspective, a year would soon go and only solid research progress would yield any chance of future funding from the SSRC. I didn't realize how important family support is during any period of active interference by state agencies in the research process, nor did I comprehend the realities of family members being a vulnerable flank through which any research activist can be attacked.

In times of political turbulence like now, it is especially important that researchers discuss such personal security matters with their families and agree their limits, fears and expectations. If I'd known what was in store, I would have remained a temporary assistant gardener but during those early days I enjoyed a sweet freedom to follow my research. I soon built a useful network of key individual researchers and NGO's, many of whom I am still working with to this day.

The Director of the Programme of Peace and Conflict Research, Dr. Paul Smoker was one of the founding fathers of modern peace research. Indeed he set up the first UK based peace research centre at Langthwaite House on the back road between Galgate and Caton in the early Sixties. I had cause to pass the old buildings of this first centre as I bicycled my way home from the university to the small village of Brookhouse where I then lived. What caught my attention was that Langthwaite was now surrounded by antennae and in an adjacent field there was a larger radio mast with a dish and a horn, which the locals believed was a colour TV relay station: it wasn't. The route towards challenging that local piece of folklore would involve rethinking technical capacity available for telecommunications interception, and the way that technological creep broke the boundaries of authorised tapping, checks and balances into something completely new.

\section{Truth Lies Open To All?}

Lancaster University's motto - 'Omnibus Patet Veritas' very much appealed to me. It means 'truth lies open to all'. I was fascinated by the contradictions between this ideal and 
the hidden dimensions of political control - especially in the UK where civil servants were required to sign the Official Secrets Act.

I was working on a range of different techniques for assessing new technologies of political control. This included an examination of the growth of surveillance in the UK, which had significantly changed over the last two decades. It is useful to look at the context in which this research was taking place. For example in 1957 when Lord Birkett produced the official report on telephone interception in the UK, telephone tapping was very much a cottage industry. Since then telephone interception has grown into today's hitech networks

Nevertheless when figures were officially updated in 1980, many MP's were surprised by the relatively modest official increase over the intervening 23 years: from 129 warrants in 1958 to 411 in 1979 for England and Wales. However the 1980 paper on the Interception of Communications did admit that one warrant could cover multiple intercepts on an entire organisation and its members e.g. CND. It was also revealed that the Secretary of State 'may delegate' to the civil service the power to amend a warrant. Thus the total number of lines monitored was going to be substantially more than the number of warrants issued.

Another anomaly was revealed when MP Clement Freud asked whether the number of interception orders currently in force was cumulative or whether the number given simply indicated how many new orders had been published. The then Home Secretary, William Whitelaw, refused to answer leaving open the possibility that key permanent warrants for MI5 \& Special Branch were only issued once. It might also have been supposed that the development of international terrorism in the early Seventies had further fuelled the growth of telephone surveillance. However the public record showed a different story. The sharp boom in UK telephone tapping came immediately after Birkett, who recommended that in future official figures on tapping should not be made public.

Thus the main growth period in telecommunications surveillance occurred in the Sixties before international terrorism - the ostensible reason for official surveillance in the Eighties - had become a major problem. If anything, the official record shows that the growth rate slackened in 1970, just as terrorism, particularly in Northern Ireland, had intensified. It could not be the full story. In this respect the White Paper gave a clue. It did not cover telephone tapping in the Province, nor did it cover warrants signed by the Foreign Secretary for the Government Communications Headquarters $\left(\mathrm{GCHQ}^{2}\right)$ and the Secret Intelligence Services, nor tapping warrants signed by the Prime Minister.

These were particularly significant omissions, given that just one permanent warrant signed in 1967 authorized GCHQ to intercept all overseas telegrams. Indeed the sudden drop in Home Secretary warrants after 1975 can be partially explained by this transfer of the surveillance workload from MI5 to GCHQ in conjunction with the US National Security Agency (NSA) and without reference to parliament.

Bypassing formal democratic authorisation and transparency of interceptions thus became

2 GCHQ is the British node of ECHELON - a telecommunications interceptions sub-network very much dependent on the superior technology and logistics of its bigger American Brother, the NSA 
a state norm - but how could surveillance researchers ever hope to get evidence of such a top secret network - especially since the penalties under the Official Secrets Act were draconian - up to 14 years in jail? The short answer, as is often the case, was by accident.

Whilst researching another issue of state security structures, a journalist, Peter Laurie, was updating his book, 'Beneath The City Streets' and was seeking the assistance of knowledgeable researchers such as Duncan Campbell. Duncan Campbell even then, was probably the foremost telecommunications researcher of his generation - a journalist who went on to play a pivotal role in exposing ECHELON and identifying the policy grounds needed to bring it back under some semblance of democratic control. Laurie was looking at the emergence of Emergency centres of Government being prepared for World War III, which would create secret citadels to facilitate post nuclear holocaust communication command and control.

Laurie's thesis was that many of these secret centres were beneath the key nodes in the array of new post office microwave towers, which were springing up around the UK. For Non-British readers it is worth explaining that whilst we have local cable and fibre-optic for our urban telecommunications links, once these leave cities it proved cheaper to send them longer distances by a network of microwave towers or antennae spaced at distances of approximately twenty miles. Such microwave beams are relatively accessible to interception by another microwave beam crossing their path.

Laurie had published some pictures of some of these towers in the Sunday Times and in 1977 the time was ripe to update his book and publish a full map of where the towers were located. The assumptions were completely fallacious but it led a small group of researchers to model the UK entrails of ECHELON without realizing the true significance of their activities until the state severely overreacted.

I unwittingly got caught up in the dragnet following a request from Duncan Campbell to take some pictures of my local telephone microwave node - an aerial or antennae located near a moor named the Quernmore - and also the designation of the larger antennae by Langthwaite House. What happened next proved to be a major turning point in the confidence of surveillance scholars to research state structures Apart from David Wood's (2001) excellent thesis, little has been written about the personal side of getting caught up in such an enterprise. This was my experience of mapping what turned out to be an illegal paradigm.

\section{Mapping An Illegal Paradigm}

I had been asked to conduct field research in its most literal sense. I was to go out into a field, take an image of a construct, note its configuration and share that information with a network which would use the data to affect political change. This was a perspective consistent with my overall drive. I remain uncomfortable with research which can be deemed to be 'social astronomy' or what less generous colleagues characterise as 'academic masturbation.' In my view the whole point of doing such work is to be applied, and that means directing surveillance studies to policy change. Such 'research activism' is 
easier said than done - although the first steps, in this case, are relatively simple.

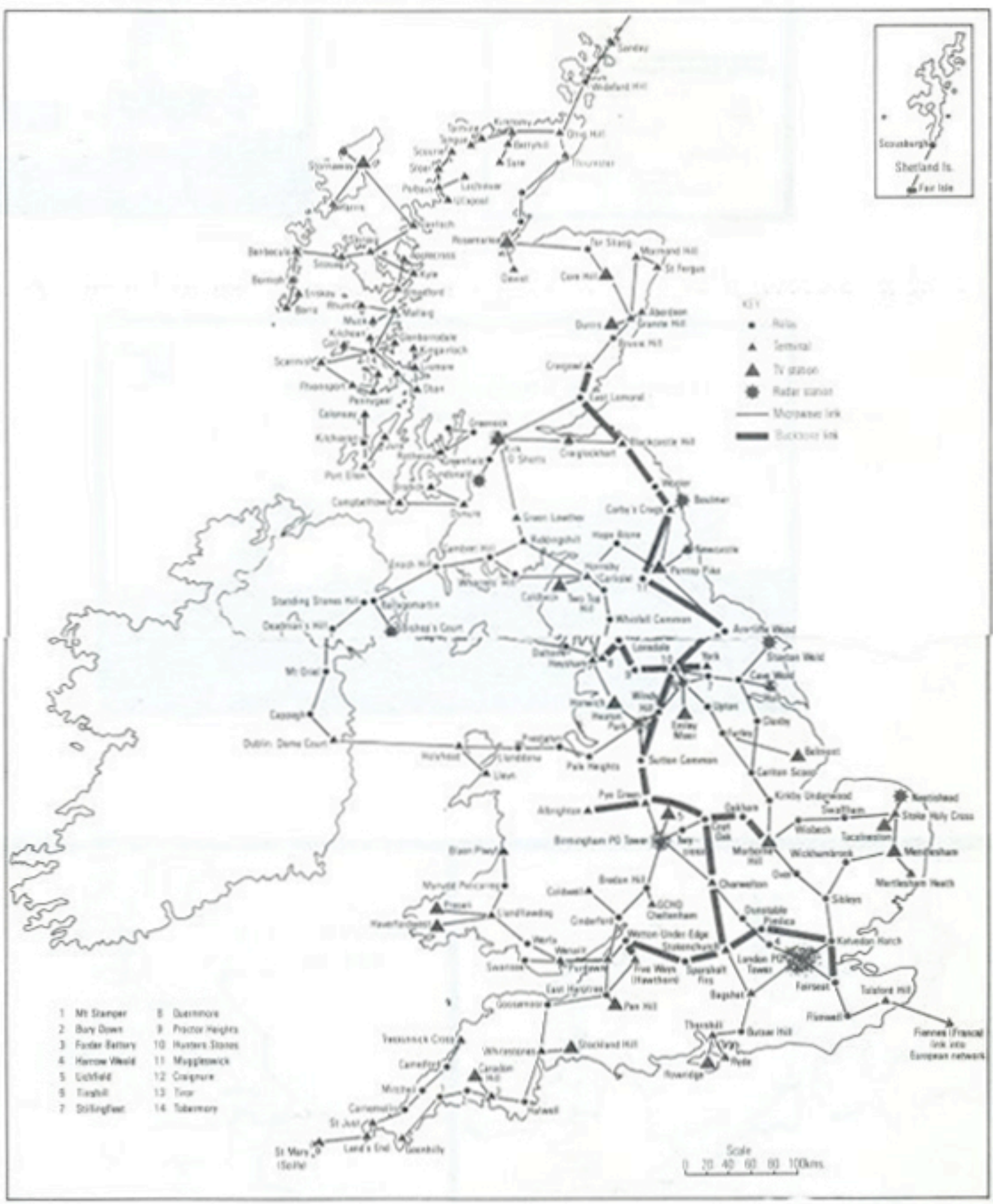

Figure 1: UK Phone Tap System 
In theory, the practical research steps required to uncover any such secret surveillance links were a technically straightforward, albeit arduous undertaking. A map of the legitimate telephone network was compiled on the basis of telephone directories and associated exchanges. This pattern of links, which are officially in place to relay calls, can then be compared with a map of relays actually found from field research. Microwaves travel in straight lines over relatively short distances so it is simply a question of using compass map and ruler to find the next relay in the grid. ${ }^{3}$ The 'field map' is then simply subtracted from the official map using what are, in methodological terms, essentially Mills' methods of addition and subtraction ${ }^{4}$. The anomalous system came to light. (See Figure 1).

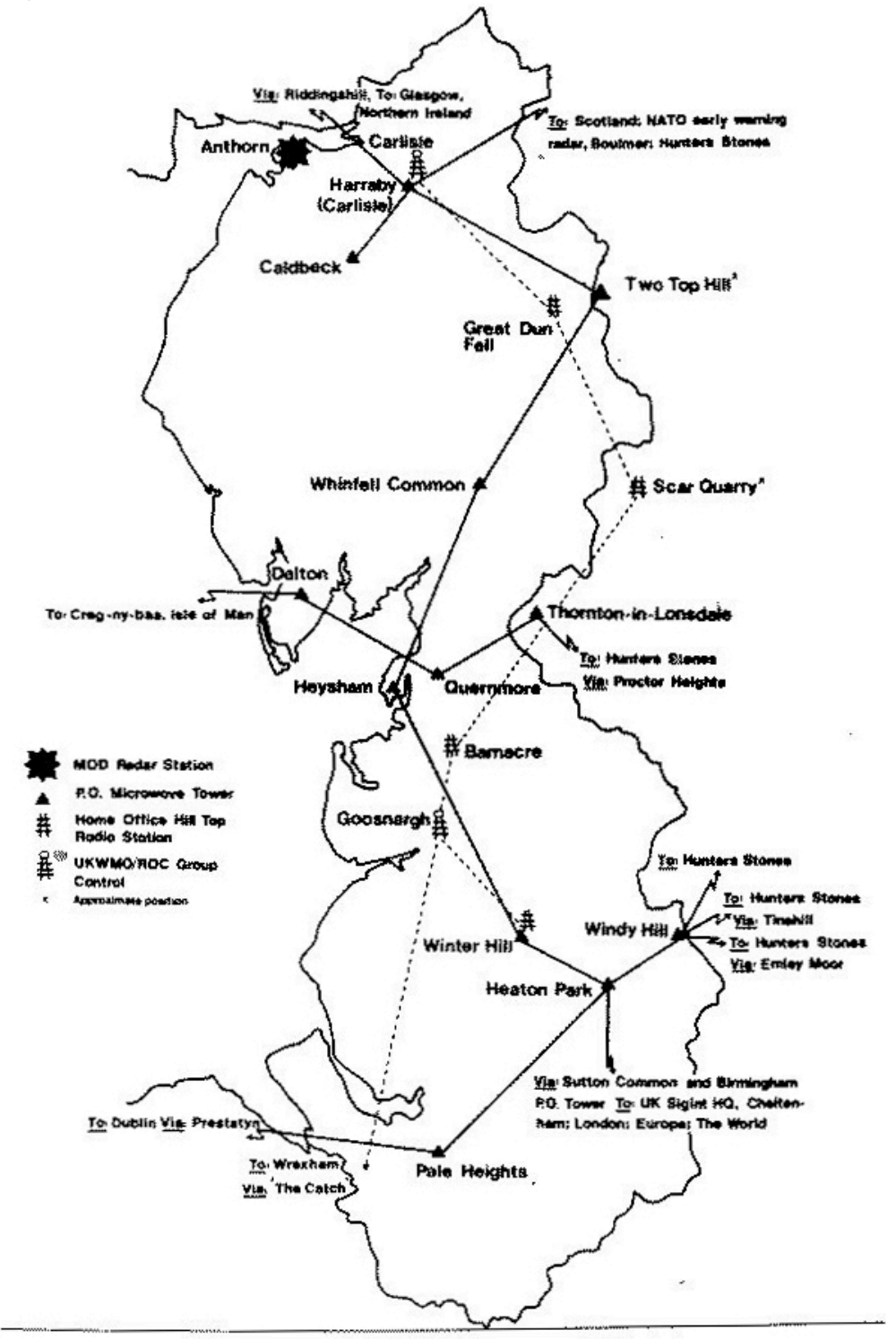

*From Poole \& Wright, Target NorthWest, 1982.

Figure 2: the location of the Quernmore Aerial

I took the original pictures during the Winter of 1977 using a simple instamatic camera, it even had shots of Damon, my baby boy, on the reel. I sent it off to Duncan Campbell, together with a map explaining that a dish faced in the direction of Northern Ireland and a horn was pointing in the direction of the Yorkshire Moors and Menwith Hill. The significance of the orientation of specific horns and dishes is that they provide a precise direction of the next link in the chain.

In fact the Quernmore aerial (Figure 2), was connected by a series of other relays such as Thornton in Lonsdale (Figure 3) and Hunters Stones via Proctor Heights before being physically linked to the NSA site (Figure 4). A short time later on February 18 1977, Duncan Campbell was arrested under section 2

\footnotetext{
3 A brief summary of all these trials is provided in Newsday, Nov. 10, 1981.

4 This is a classical methodology for identifying logical arguments of induction and deduction
} 
of the Official Secrets Act, because he and a fellow journalist met with a soldier to discuss questions of signals intelligence. Nothing much of significance was exchanged that night but because Campbell's telephone was bugged, police knew of the meeting which was a technical breach of the British Official Secrets Act which all members of Her Majesty's Forces sign. Once Duncan was arrested, his correspondence addresses provided the target list for further arrests - including one chap who sent him a Christmas card, and in the end, me.

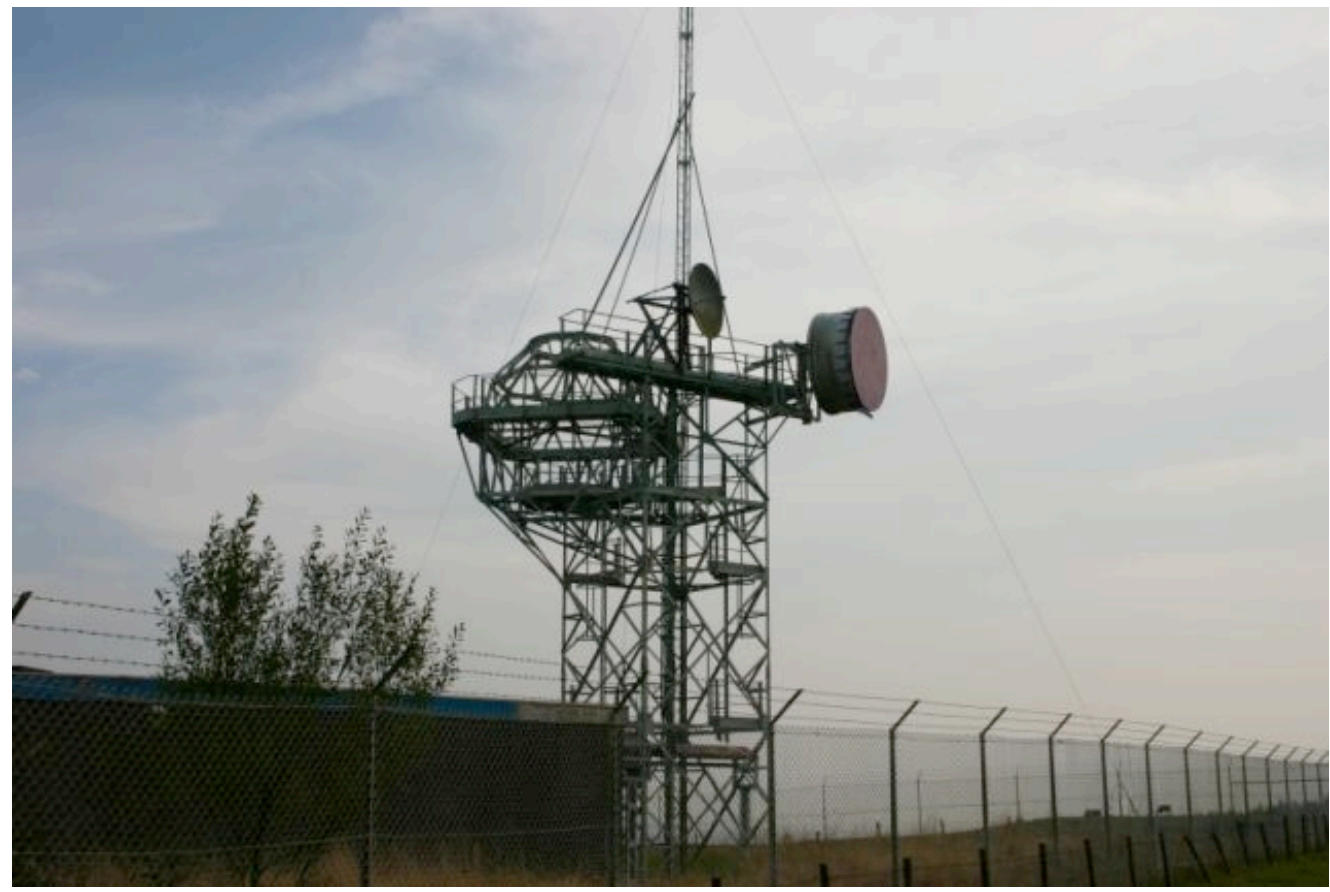

Figure 3:

The

Thornton

Relay

Researching such systems was previously thought to be legal, if only open sources were used. How can a secret be a secret if it isn't really secret? After all, the Sunday Times had already published a compendium of such aerial photographs. The mistake in this assumption was that research on intelligence could easily be re-designated by the authorities as intelligence itself. The added value of what could be seen as 'mere' academic modelling was that an analysis of classified data would have yielded the same results. The research paradigm was then tantamount to an illegal vision and although the logic seems very 'Alice in Wonderland', the same tactics to challenge researchers were used repeatedly during that period. There were several testing trials of researchers attempting to understand the role and function of arrays of various antennae in those days using just open sources. The ABC trial in England (essentially the Duncan Campbell case), the Rabbit Trial in Oslo which centred on peace researchers who were examining secret configurations of such antennae in Norway, the Wilkes Trial in Sweden which used various open lists to model military activities and the Christensen trial in Denmark. The military authorities in all these cases attempted to legally restrict empirical research on state surveillance structures. ${ }^{5}$

\footnotetext{
5 A brief summary of all these trials is provided in Newsday, Nov. 10, 1981.
} 


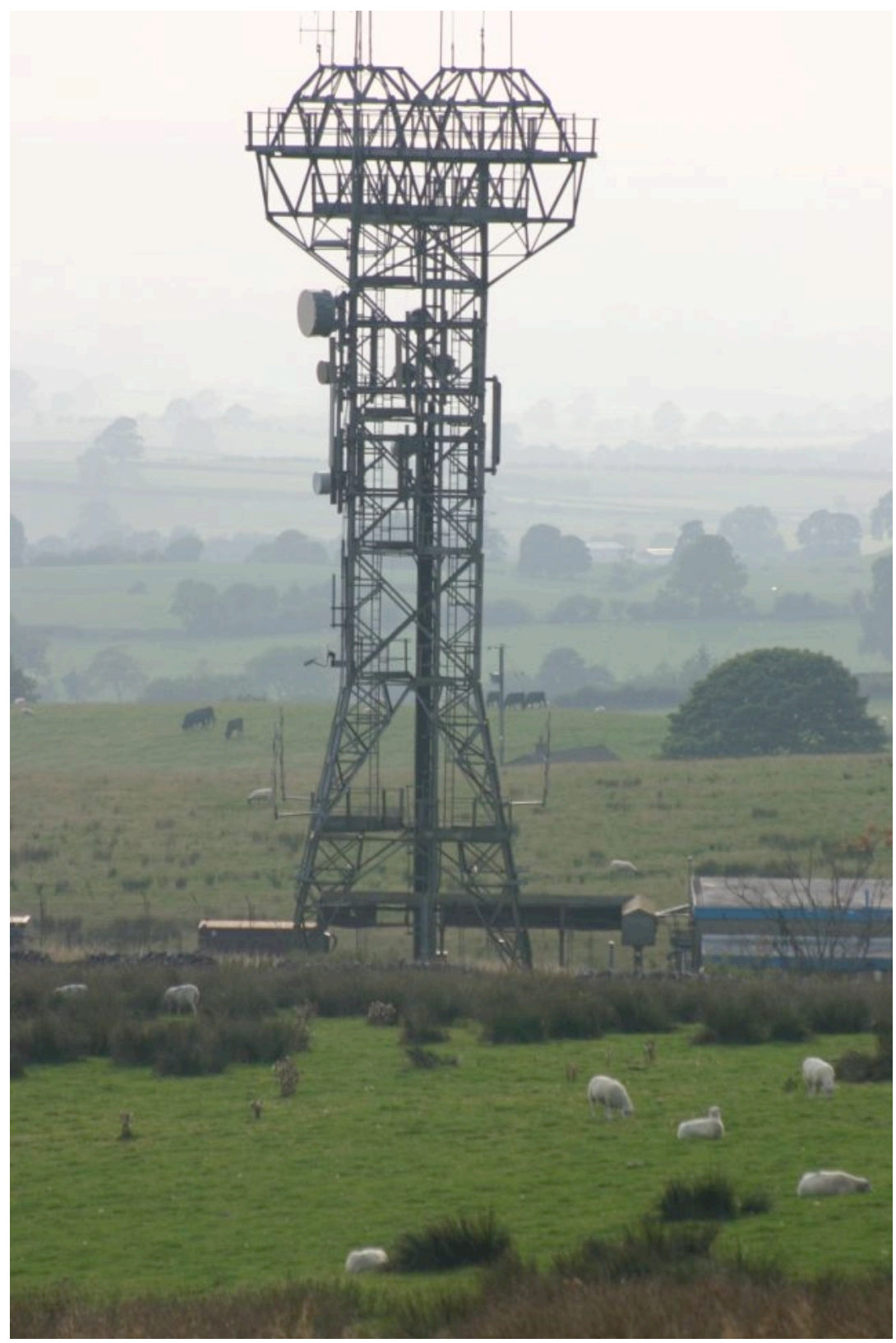

Figure 4:

The terminal at NSA Menwith Hill

\section{The Special Branch Raid On Lancaster University}

Not all knowledge is from rational sources. Even the term paranoia literally means 'beyond knowledge (para: beyond; noia: knowledge). On the night of $5^{\text {th }}$ April 1977 I had a stormy, seemingly pointless argument with my wife. In frustration I declared that my wife didn't understand the work in which I was engaged and 'one day my work would walk through the front door.' The instant response, quite deservedly, was 'you're being melodramatic - I'm going to bed!' I reflected on this afterwards thinking it was a bit melodramatic and that I was making needless emotional waves. 
A few hours later loud knocks on the door heralded the arrival of 6 Special branch officers who make it clear that they wanted co-operation otherwise they will use 'blatant search techniques'. This implied that not only would they turn the place over but that the search would become very obvious to the neighbours. Without the argument of the night before, I might have caved in. Because of it and a silly sense of 'I told you so' I calmly suggested that what they were doing infringed academic freedom and was unprecedented. This episode of déjà vu was so well documented in the light of subsequent events, Brian Inglis used it in his book, the Hidden Power. The lesson here is whilst one should never give way to paranoia, it is useful to develop and trust your intuition. Our minds are capable of intuitive leaps which are ours to use even if we can not necessarily rationally explain them and the history of science is full of such episodes. Our challenge is to use hunches as a methodology to conjecture with or refute.

In fact my then neighbours were so alarmed by the presence of six burly strangers strolling around our house they called the local police! The officer knocked on our door and was given short shrift by Detective Chief Inspector Moffat of Scotland Yard, who told him, 'It's official so piss off'. I queried what it was that I was alleged to have done and the Kafkaesque atmosphere was heightened by the response that it is an official secret and I cannot be told. In the meantime, my diaries and entire research correspondence were removed. I discovered later that the police don't steal, the technical term is detinue - i.e. they hold on to items longer than they should, a matter which can be devastating if a researcher is working to pre-set deadlines.

In this heavy atmosphere of confrontation with secret police officers, it would have been easy to roll over but I felt it was important to stand up to their infringement of my rights to research. How was another matter. I could easily see how my academic future could be blown out of the water if a full secrets trial resulted from what was to all intents and purposes a fishing expedition.

I was taken by car to Lancaster University. It was the Easter holiday period and the special branch officers expected 'that a bit of arm twisting' would give them easy access to my offices in an otherwise empty campus. But the politics department was crawling with academics who were demanding proper procedures be followed. After some delay, I thanked the officers for their lift to campus and announced that I had work to do and proceeded to exit the car. This forced their hand and I was arrested under the official secrets legislation and taken to meet with Professor Phillip Reynolds the Pro-Vice Chancellor, together with various university and college officials who had assembled: Dr Roxbee Cox, Fylde principal and Mr. Forrester, Academic Registrar.

The atmosphere was tense. Special Branch demanded access to my room and I pointed out that principles of academic freedom were involved. After all I had only ever used open sources, had simply followed the university motto and no one had explained the nature of any charges laid against me. Detective Chief Inspector Moffat replied that 'this was an issue of national security' and told me that they had a warrant. Professor Reynolds demanded that they go through the proper channels, to which Moffat replied that he had six men present and would start breaking down doors in the department if access was denied. People began sweating - it was an unforgettable moment. I broke it by emphasizing that I had nothing to hide and suggested that they could search to their 
hearts' content. ${ }^{6}$ The atmosphere was thankfully lightened a bit later with the arrival of my supervisor, Dr Paul Smoker, who amidst the hub bub in the corridors managed to give me a burst of the Beatles hit, 'Listen Do You Want To Know A Secret - Do you Promise Not to Tell?' Perfect: but I was later held in Lancaster Police Station for several hours, refused a solicitor and when finally released was told, sometimes you fellows are too clever for your own good.'

The raid turned my research plans upside down not to mention the impact it had on my personal life. However it was many times worse for the main researchers, Crispin Aubrey, John Berry and Duncan Campbell (now deemed the ABC defendants), who were facing the full rigours of an official secrets act trial. And yet there was a puzzle: why had Special Branch undertaken such a foolhardy exercise as to raid a British University - how come I'd touched on a raw nerve? It quickly dawned on me that I had inadvertently stumbled on a network connected with the configuration of the antennae I had photographed on the Quenmore Moor, which the authorities were desperate to keep secret. It seemed incomprehensible. I knew that Menwith Hill was a US base, but what was the link with UK phone lines, and especially the link to Northern Ireland? Just where were the results being transmitted - to the US, but how - by satellite?. The system must be huge. It felt like a science fiction movie.

We now know that most US intelligence is gathered by signals intelligence using huge computers to trawl through the worlds' telecommunications looking for selected key words using a complicated algorithm and dictionary system of key words and operated by the NSA (the National Security Agency). At that time hardly anyone had heard of the NSA despite the fact that it was the largest purchaser of computers on the planet. The days of intelligence gathered by James Bond characters or Human Intelligence (Humint) are long gone. What we didn't know was that the US Base at Menwith Hill, with its field of radomes, was the largest NSA base on earth with many roles and function of which ECHELON was just one. It was and is involved in missile monitoring and guidance as well as satellite monitoring and control. But at that juncture all we had were jigsaw puzzle pieces and we had begun to build a model of a futuristic system of interceptions - the bulk of which as we know now, is in space. The fuller model could only be developed later as further jigsaw pieces fell into place.

However, the pragmatics of defending my position became all consuming. The university provided me with a Lancaster lawyer. He advised me that he had been told by the Special Branch officers that the researchers I have been co-operating with are extremely dangerous people and that I should cut off all contact with them. I developed the strong impression that this fellow was more used to matrimonials and conveyancing. Worse - I was paying for this disinformation. In such circumstances, one has to experience a rather steep learning curve. I sacked my solicitor and found a much more expensive firm from Liverpool: Bremner, Sons and Corlett, who were more used to dealing with Special Branch and who took a tad more professional approach in following their client's wishes. I was advised that if I wished to take legal action to regain my papers it must go through a higher legal authority and I would have to meet with a barrister in Chambers. As a very

6 For a contemporary account of this episode see Lawrence, B. (1977) 'Nasty Branch hit Bailrigg, Scan, Edition 1, 26 Aprll, page 1 
poor student, the financial implications were horrendous and I could see a significant chunk of my terms grant disappear in legal fees.

I was told that the lawyers for the $\mathrm{ABC}$ defendants had been faced with considerable official paranoia over the case and that they were not being allowed to receive the trail committal papers unless their offices were equipped with high security safes. The succinct legal advice I was given was that if I continued in the task of trying to get by research papers back, ' my future research, career and even my life would be in danger.' I clearly needed a stiff drink after that and some further moral and political support. I went to see the then VC, a wise Quaker, Sir Charles Carter who had been influential in setting up the first Programme of Peace research in the University.

After our meeting, on the $5^{\text {th }}$ May 1977 , he released the following statement:

Those who work in universities cannot expect to be exempt from the application of the law, but they can reasonably ask for sympathetic understanding of their duty to seek access to all evidence relevant to their studies. Truth is not something to be determined by the state.

This was an important intervention which received national publicity. By coincidence, the Student Union had invited Duncan Campbell up to Lancaster from the ABC solidarity committee. He was able to take a copy of the statement to Robin Cook MP (Cook who died earlier this year, went on to become British Foreign Secretary and eventually father of the House of Commons)). Cook opened the first ever British parliamentary debate on the Special Branch and defended my right to research without political interference. ${ }^{7}$

There was certainly political interference. We started to receive odd threatening phone calls at home, finance was desperate and I had just weeks to bid for continuing grants. My marriage could no longer take the strain and we separated on 7 June 1977 as the rest of the people in our street celebrated the Queens Silver Jubilee. A few weeks later, my wife's father had a heart attack and died and in deep grief she had a breakdown which eventually involved me in extracting her from the hospital and attempting to heal her troubled heart. But it was too late, the damage had been done and I had to go to ground. I got a job digging fields for $£ 1$ an hour, just within sight of the shadow of the Thornton in Lonsdale microwave tower. It was a completely desolate time but I vowed that one day I would get justice for the injustice that I had endured. It was a powerful mantra but there was no guide book as to how such a lofty goal could be achieved: just patient persistence. Twenty years would pass before I would get my chance. In the meantime, my lawyers obtained copies of my research correspondence, I was released from police bail, the ABC defendents fought and won their freedom in one of the most dramatic political trials of the 1970's and I got back to the business of completing my $\mathrm{PhD}$. All the surveillance researchers of that era had quickly realised just how important it was to join together to research state structures, if they are not to be picked off one by one when a particular security alert gets out of hand.. From that crucible, the first regular journal monitoring state surveillance was born - State Research (now Statewatch) which continues its excellent ground breaking work to this day.

7 Hansard 5 May 1977, col 806 


\section{The Omega Foundation}

It was a long time before I could create the requisite networks of solidarity and understanding, moving to Manchester in 1981 to return to my roots after the riots of the summer when I published a full page article in the Guardian about the hard military policing style which was on the horizon. Oftentimes I felt like a sorcer's apprentice but in 1984 I succeeded in my application to become Head of Manchester City Council's Police Monitoring Unit. This provided a firm grounding in politics as 'the art of the possible' as well as providing ample opportunities to re-examine police accountability. It also brought me back into contact with Tony Bunyan who had been a central figure in the $\mathrm{ABC}$ Defence Committee and a solid source of insight and support during those difficult times. Tony was now the head of London's Police Monitoring Committee with an awesome remit. He was and is a great teacher on how even small group in civil society can make a political change.

In 1989, after the demise of the Police monitoring initiatives in the UK as the leftwing Labour City Hall Council's which had originally financed them, lost ground to the Labour political right, I went on to work a trusted friend to set up the Omega Foundation, to track the proliferation of military, police and security equipment to the torturing states.

\section{Scientific And Technological Options Assessment (Stoa) And An Appraisal Of The Technology Of Political Control}

In 1996, the Omega Foundation was commissioned by the European Parliament to write 'An Appraisal of the Technologies of Political Control.' Late in the day, I decided that maybe the time was right to raise the issue of the interception of communications. Duncan Campbell had returned to the subject in $1988^{8}$ and recently that work had been extended by the New Zealander Nicky Hager in his book 'Secret Power." ${ }^{9}$ It was complete serendipity since I accidentally came across adverts for the book in Washington whilst visiting Terry Allen, then editor of Covert Action Quarterly.

It raised important issues about political control of a system which could technologically bypass any constitutional guarantees any state had protecting citizens from illegal surveillance. Its existence went beyond just privacy, a global network of surveillance which could target financial and political institutions was an instrument for political management: ubiquitous but invisible.

I also wanted to include new work on the FBI's collusion with EC authorities to get more intimate access to European telecommunications for policing purposes. Tony Bunyan had hundreds of documents on this but in the winter of 1996 had yet to write them up. I inadvertently gate crashed the Statewatch staff Christmas party and in an expansive mood, Tony Bunyan agreed to publish his findings in the next issue of Statewatch. I could then quote his report as an authoritative source in the report I was writing for the European

\footnotetext{
8 Campbell, D. 1988 They've got it taped, New Statesman, 12 August.

9 Hager, N. (1996) Secret Power: New Zealand's Role in the International Spy Network, Craig Potton Publishing, PO Box 555, Nelson, New Zealand.
} 
parliament's Science \& Technological Options Panel, which was deadlined for March 1997. However, it did not go to committee until December 1997 and would have been largely ignored had it not been for a Daily Telegraph article by Simon Davies which alerted the international media.

\section{ECHELON Exposed}

The section dealing with ECHELON in the STOA report only ran to a few pages. The paragraph which drew most attention concluded:

Within Europe, all email, telephone and fax communications are routinely intercepted by the United States National Security Agency, transferring all target information from the European mainland via the strategic hub of London, then by satellite to Fort Meade in Maryland via the crucial hub at Menwith Hill in the North York Moors of the UK. Unlike many of the electronic spy systems developed during the Cold War, ECHELON is designed for primarily non-military targets: governments, organisations and businesses in virtually every country. The ECHELON system works by indiscriminately intercepting very large quantities of communications then siphoning out what is valuable using artificial intelligence aids like Memex to find key words. Whilst there is much information gathered about potential terrorists, there is a lot of economic intelligence, notably intensive monitoring of all the countries participating in the GATT negotiations. With no system of accountability, it is difficult to discover what criteria determine who is not a target.

Nothing in the STOA report was new but its packaging in a formal report for the European Parliament led to a 'tipping point'. Interest in ECHELON mushroomed and all the European Member States had parliamentary debates about it. In September 1998, I was asked to produce an edited study updating the earlier report and included calls for a series of new studies to determine the level and extent of ECHELON's activities. Of these, Duncan Campbell's Interception Capabilities 2000 was the most informative and helped to redefine our knowledge of the role, function and activities of ECHELON. ${ }^{10}$

These reports laid the foundation of the European Parliament's temporary ECHELON Committee, which created some of the best most informed organised knowledge on the existence of ECHELON, its activities and limitations. ${ }^{11}$ Almost every serious newspaper in the world has now covered ECHELON. Why? Because one package of organised knowledge, put together in a serious format was able to catalyse subsequent interest. Nevertheless, that package in itself was the fruit of scores of other researchers' activities, not least, the courageous Menwith Hill Women's camp activists who gleaned much of the secret documentation on which Duncan Campbell based his studies. The documents were

10 See http://www.iptvreports.mcmail.com/ic2kreport.htm accessed December 2005

11 For the final report see http://cryptome.org/ECHELON-ep-fin.htm accessed December 2005 
'liberated' via the time honoured research methodology of 'bin-ology' - the illegal raiding of bins and plastic rubbish bags inside the base.

\section{Conclusion}

The moral of the ECHELON story is that a network of researchers can both model, reinterpret, understand and politically challenge even awesomely funded and politically sensitive surveillance organisations such as the NSA (although I might admit to having second thoughts if I had seen the Gene Hackman movie 'Enemy of the State' before I wrote the STOA report.) Even at that juncture, the early reception of the European Parliament was hostile in some quarters with questions about whether ECHELON even existed.

However, the STOA report contained detailed recommendations for further work on understanding new surveillance technologies and their political impact including the commissioning of new work on ECHELON. It was no coincidence that on my recommendation, the author of the key final document proving ECHELON's role was Duncan Campbell, the original ECHELON researcher and ABC defendant. His report, to STOA, Interception Capabilities 2000 remains one of the clearest expositions on the way that ECHELON works as well as a healthy self-critique of some of the assumptions made including the capacity of the NSA to do continuous real time speech recognition, authentication and direct printout. There were limits but these were burgeoning new research areas too. These reports provoked an intense debate in the European Parliament and the setting up of a Temporary ECHELON Committee ${ }^{12}$ There is now a rich literature on ECHELON which stretches way beyond what any one researcher could have accomplished. The more important sites are available via Surveillance and Society home pages. How was that paradigm shift achieved? Essentially by a network of researchers working on a variety of different jigsaw puzzle pieces - with one researcher injecting these findings into an appropriate political arena, at the right time.

Has the debate continued? Well yes and no. Immediately after the terrorist attacks on New York in 2001, I requested the STOA committee investigate the political implications of the failure of ECHELON to pre-empt the attack on the basis that such a highly invasive intelligence set up could only justify its existence if it was a prophylactic entity preventing such atrocities before they happened. STOA did commission the report but to its own chosen think-tank. There was not going to be any deeply critical NGO questioning of the role and functioning of sensitive intelligence agencies this time.

After 9/11, the debate rumbles on and many are beginning to fear that in the future such collaborative research will be thwarted by bogus security requirements and restrictions. Research scholars have to take the long view, assemble their findings and grow the supportive networks necessary for sustaining their effective work in the future. To quote my former supervisor, Paul Smoker - every major change requires a happener - and if it has happened - it's possible! It would be good to see these pages being used to explore

12 A full copy of interception capability 2000 can be found at http://www.iptvreports.mcmail.com/interception_capabilities_2000.htm accessed December 2005 
the new role of ECHELON post 9/11. At a time when the newly joined former Eastern European states are being used for 'rendering' a.k.a. torturing political detainees, we might anticipate that ECHELON is being offered to many more policing and foreign intelligence agencies in the so called 'War Against Terror'. It is fairly probable that new algorithms for tracking down friendship networks and associates have emerged, based on what could well be dodgy social science assumptions of 'proximity equals collusion'. How can we locate the new ECHELON in the new world order? In the surveillance world, ECHELON and the NSA are the equivalent of the $900 \mathrm{lb}$ gorilla. It is a challenge that future surveillance scholars will have to face.

\section{References}

Campbell, D. (1988) They've got it taped, New Statesman, 12 August.

Hager, N. (1996) Secret Power: New Zealand's Role in the International Spy Network Nelson, New Zealand: Craig Potton Publishing

Inglis, B. (1986) The Hidden Power London: Jonathon Cape

Laurie, P. (1970) Beneath the City Streets, Harmondsworth: Penguin

Lawrence, B. (1977) Nasty Branch hit Bailrigg, Scan 1, 26 April: 1

Snow, C.P. (1959) The Two Cultures and the Scientific Revolution, Cambridge: Cambridge University Press

Wood, D. (2001) The Hidden Geography of Transnational Surveillance, Unpublished PhD thesis, University of Newcastle upon Tyne, UK. http://www.staff.ncl.ac.uk/d.f.j.wood/thesis.htm [Accessed 01/12/05] 